\title{
МОДЕЛЬ РАЗЛОМНО-БЛОКОВОГО СТРОЕНИЯ И ФОРМИРОВАНИЯ ЗАЛЕЖЕЙ УВ АЛЕКСЕЕВСКОГО МЕСТОРОЖДЕНИЯ
}

Краиаков Д.В., Бочкарев В.А., Остроухов С.Б., Крашакова А.В. (ООО «ЛУКОЙЛ-ВолгоградНИПИморнефть», "ЛУКОЙЛ Оверсиз Сервис Л.т.д.")

Исследования проведены на материале Алексеевского месторождения в Волгоградской области, по которому получены новые результаты: переинтерпретация сейсморазведочных работ по 14 профилям 2D, бурения и опробования скважин $1,2,3,4$ Алексеевских, геохимических данных.

Залежи нефти установлены в песчаниках бобриковского горизонта и в известняках турнейского яруса. Месторождение приурочено к НиколаевскоГородищенской ступени Прикаспийской впадины. Из ранее простого (пликативного) строения залежей с активным гидродинамическим режимом структура приобрела отчетливо выраженный мелкоблоковый характер строения с замкнутым гидродинаминеским режимом залежей в каждом блоке. Месторожсдение распалось на три самостоятельных эксплуатационных объекта, приуроченньх к блокам, в каждом из которьх залежи имеют собственные ВНК и условия разработки.

Залежи нефти в каменноугольных отложениях в сложившихся структурных условиях формируются в ловушках структурно-тектонического типа. На уровне продуктивных отложений все сбросы являются экранами (закрытыми) для межблоковой (горизонтальной) миграция пластовых флюидов по одновозрастным пластам. В тоже время пологие продольные сбросы обеспечивают вертикальное перемещение по ним флюидов (сброс 1С) за счет создаваемой при смещевии блоков зоны дробления пород (ЗДП). Как правило, примыкающие к ЗДП пласты пород-коллекторов вследствие их высокой и повыпенной трещиноватости (дилатантное разуплотнение) могут обладать и больтей продуктивностью. Мигрирующие по верхней кромке ЗДП УВ при встрече с пластом-коллектором поступают в ловупку, степень заполнения которой определяется наивысшей точкой сечения пласта верхней линией ограничения ЗДП или точкой оттока УВ. Мигрируюпие таким образом по сбросу $1 \mathrm{C} \mathrm{УВ} \mathrm{заполняют}$ нефтью все ловушки в каменноугольных отложениях опущенного в сторону впадины блока.

Формирование промышленных залежей УВ в выделенных блоках можно разделить на два этапа. На первом уже $\mathrm{K}$ началу верхнекаменноугольного периода нефтегазоматерин- ские отложения девона и нижней части раннего карбона находились в погруженных частях западного борта впадины в условиях ГЗН. Знадительная доля нефти на пути латерапной миграция из материнских проницаемых пород зоны генерации при достижении ЗДП сбросов проникала по нарушению в вышезалегаюшие отложения, в том числе и в пределы Алексеевской структуры, заполняя со стороны сброса последовательно все ловушки в примькающих к нему пластах-коллекторах. На втором этапе материнские породы оказались в ГЗГ, в которых идут активные процессы генерации и эмиграции УВ газов. На путях миграции газоконденсатных растворов проис- ходят процессы перераспределения ранее сформировавшихся залежей. На Алексеевском месторождении газоконденсатные растворы, первоначально вытеснили нефть из ловушек в девонских отложениях (скв. 238 Быковская, приток газа из интервала 5577,0-5601,0 м). Затем двигающийся по ЗДП смесителя сброса газоконденсат поступает в пределы нефтяных залежей турнейского возраста. В результате к нефти ранней генерацни добавилась нефть, а затем и газоконденсат более поздней генерации (смешение и растворение), обеспечивая рост давления насьпцения нефти газом и газовый фактор. УГлеводородная смесь (нефти и растворенного в ней газоконденсата) имеет таким образом различный генезис ее основных составных частей. На активность генерационно-аккумуляционной системы поступления и распределения УВ в продуктивных отложениях месторождения на современном этапе подтверждается наличием глубинного гелия с его неспособностью к дпительному сохранению в составе свободного $(0,03$ мол \%) и растворенного в воде $(0,02$ мол \%) газа.

При создании геохимической модели выявленных залежей месторождения использовались фазово-генетические исследования нефтей на основе их молекулярного состава, что позволило выявить две группы нефтей по содержанию в них низко- молекулярных УВ до состава $\mathrm{C}_{13}-\mathrm{C}_{15}$. K первой группе, с высоким содержанием низкомолекулярных УВ, относятся нефти скв. 2 и 3. Ко второй группе, с низким содержанием низкомолекулярных УВ, - нефти скв.1. В нефтях первой группы выделяются две зожы: первую составляют низкомолекулярные алканы до состава $\mathrm{C}_{16}-\mathrm{C}_{17}$, вторую - алканы состава выше $\mathrm{C}_{17}$ с максимум концентрации на $\mathrm{C}_{20}$ $\mathrm{C}_{21}$. Наличие двух зон указывает на то, пто флюид представляет собой смесь двух природных соединений: первая зона отражает в нефти газоконденсатную составляющую, а вторая характеризует состав первичной нефти. Полученные результаты геохимического моделирования, подтверждае- мые дапными эксплуатации залежей, указывают на то, что скв. 2 и 3, с одной стороны, и скв. 1 - с другой, находятся в разных блоках. Залежи нефти в них формировались в два основных этапа. Современный облик (состав и свойства) нефтей обусловлен усиливаю- щимся подтоком по сбросу газоконденсатных растворов из зон (источников) их генерации в сформированные на первом этапе нюжнекаменноугольные нефтяные залежи Алексеев- ского месторождения. Отсутствие генетического единства и различие в степени термодина -мической преобразованности между «газоконденсатной» и «нефтяной» составляюшими указывает на более поздний мкграционный характер первой группы нефтей. 